\title{
CODE-SWITCHING: STATE-OF-THE ART
}

\author{
Elena A. Krasina, Jabballa Mahmoud Mustafa X. \\ Peoples' Friendship University (RUDN University) \\ Miklukho-Maklay str., 6, Moscow, Russia, 117198
}

\begin{abstract}
Code-switching is one of the aspects to study the immediate results of language contacts which supposes that intra-sentential analysis of morpho-syntactic structures could explain the causes and reasons of language borrowings in synchronic linguistics. It also involves psychological and social aspects of human behaviour, but confines itself to linguistic analysis. At present three main theories which are language rooted and the most developed ones govern code-switching research, namely, linear order constraint model of S. Poplack et al.; linear order non-constraint model of N. Chomsky and E. Woldorf and Matrix Language Frame model elaborated by C. Myers-Scotton. All the three proceed from the idea of a monolingual grammar regulating code-switching process, though in Chomskyan model such monolingual grammar is substituted with the Universal Grammar in combination with generative grammar rules. The C. MyersScotton Frame model seems more complicated as it is organized as a double-headed instrument: dominant Matrix Language doesn't eliminate the factor of Embedded Language which in course of their interaction creates a kind of collaboration. All the three models basically deal with a sentence structure and thus are in fact intra-sentential studies, though the conclusions are also made on the morphological and even phonological aspects of the utterance. Lexicon of languages in contact is practically neglected in the studies but N. Chomsky, and J. MacSwan and C. Myers-Scotton pay attention to lexical borrowings; they prove the importance of those by developing the notion of nonce borrowings specific representation of culture and tradition. In fact the present day state-of-the art in the domain of code-switching base itself upon observation and language samples accumulation in course of analysis of structural features of contacting languages. The shortcomings of the approach might be motivated by the fact that typological language features are not applied, so the analysis lacks a solid background bringing in random data without any classification possible. Thus one may assume that main results at a present level of research could be found in the sphere of methodology and methods. As to code-switching terminology it's in course of development: even the notion of 'code' in our opinion needs more precise definition as it originally refers not to language itself but to semiotic systems of various origins and nature.

The directions for future research do not confine themselves to bilingual or multilingual data, but mean to deepen the multidisciplinary studies of language contacts and verify the reasons for code-switching through the complex of humanities and natural sciences applied to linguistic items and codes.
\end{abstract}

Keywords: language contacts, code-mixing, code-switching, borrowing, linear order constraint/ non-constraint model, Matrix Language Frame model, intra-sentential, insertion

Code-switching is the alteration of two languages within a single discourse, sentence or constituent.(...). It is only by linking ethnographic observations with linguistic analysis that code-switching behavior may be most adequately explained.

Shana Poplack, 1978

\section{INTRODUCTION}

The present day situation in teaching and learning languages is determined by the fact of widely spread language contacts and as a consequence bilingualism-multilingualism studies as a interdisciplinary studies. One might assume that nearly $100 \%$ of global 
population of both the Generation Y or Millenarials born in 1983 - 2000, and the Generation X or Centanarians born after 2000 are bilingual speakers which causes the appearance and spread of Franglais, Spanglish, Runglish and "other Englishes" in the domain of Globish. Famous SAE doesn't seem to be the term sufficient enough to form the background to describe and study language interaction worldwide anymore. So, as the studies of language contacts involve national languages, their dialects and other variations, the core research areas in the field include: the representation and processing of languages in the bilingual mind, childhood and adult language acquisition, bilingual speech disorders, bilingualism and mixed linguistic systems, effects of bilingualism on individuals and societies, bilingualism and educational challenges, language endangerment, and extinction among others, etc., which involve psychological and social aspects. But linguistic approach provides the data to be analyzed and approved and is bearing its own characteristics belonging to language system. In this field the phenomena of code-switching is the one that focuses researchers attention to language mixing which used to be supported by monolingual formal grammar. Starting from 1970s, non-formal theories have emerged and focused on the so-called real life situations when a speaker knows and uses more than one language and mixes aspects of those languages to a certain - greater or lesser - extent. Such a bilingualism-multilingualism has brought to life a new set of terms functioning in a new linguistic research domain, firstly, the term of code-switching.

\section{ANALYZING DEFINITION: WHAT IS CODE-SWITCHING?}

The origins of code-switching seem to date back to mid-XX century as a multidisciplinary convergence in the field of science: R. Fano's information theory [1], structural phonology developed by $\mathrm{Ch}$. Fries and K. Pike [2] and bilingualism as introduced and described by U. Weinreich, E. Haugen, H. Vogt [3-5]. As was supposed the term "code-switching" reflected not uniquely a linguistic phenomenon but rather a psychological one, or their combination, so from the very start it was a multidisciplinary term [5: 368].

In his classical work on language contacts, U. Weinreich (1968) describes the ideal bilingual speaker as the one who can "switch from one language to the other according to appropriate changes in speech situations (interlocutors, topics, etc.), but not in an unchanged speech situation, and certainly not within a single sentence" [3: 73]. The terms actually presented with the verb switch.

Research on code-switching started in two aspects - structural and sociological, and just in linguistic structural studies terminological confusion came into being: in a way, the terms of code-switching, code mixing, borrowing, or code-alternation were competing. Still, the main pair of terms used is code-switching and code-mixing.

Firstly, code as a term needs some comment. It is understood as a neutral nomination of a linguistic variety - either a language or a dialect, but some researches extend the notion of the code and apply it to denote a style-shifting in monolingual speech thus mentioning the variety of 'monolingual code-switching' [6: 121]. Some researchers even omit code in their definitions: CS is "the alternative use by bilinguals two or more 
languages in the same conversation [7: 7]. In fact they use CS as a cover term to denote different forms of bilingual behavior. The same approach is shared by J. MacSwan denotes code-switching as "a speech style in which fluent move in and out of two (or more) languages" [8: 55].

Similarly, C. Myers-Scotton uses CS as a cover term meaning under it "alterations of linguistic varieties [italics added] in the same conversation [9: 1] so it means that switching can take place not only between languages, but also between dialects of the same language.

Within the social approach to CS studies, J.J. Gumperz translates the term as "juxterposition within the same speech exchange of passages of speech belonging to two different grammatical systems or subsystems [10: 59]. S. Poplack treats the term in the same direction using as a key word juxterposition [11].

Some researchers use the term code-alteration (see: [12]) as a hyponym to replace $\mathrm{CS}$ and it's really seems synonymic to code-alteration.

Another trend in the terminology of the field is to prefer code-mixing in the sense to specify intra-sentential switches only which requires the discourse integration of the rules of the two languages involved (e.g., [13; 14]).

As was already said, some researches avoid the term code-switching as a cover term as they believe switching occurs only between turns of sentences, but not insertions ipse se (see: [15]) They choose code-mixing as a cover term for both code-switching (intra-sentential switch only) and borrowing (e.g., [16]). Therefore, the question of distinction between code-switching and borrowing seems rather urgent (see: $[11 ; 18])$ which is more important than the distinction between code-switching and code-mixing within the structural aspect.

Classical definition of the term was elaborated by E. Haugen who denoted codeswitching as a process of colloquial usage absolutely foreign word while speaking native or another language without any kind of its assimilation ([4: 40]). This is an example of language spread which causes both linguistic transfer and integration. Practically simultaneously R. Jackobson attributed the notion of code-switching to the change which monolingual or bilingual speaker should apply while decoding the speech of another person in course of communication (see: [19]) following R. Fano's understanding any code as a mechanism of exact signal transmission between the two systems in communication.

\section{THREE LINGUISTICALLY ROOTED CODE-SWITCHING MODELS}

Due to the multidisciplinary approach the term code-switching is applied in several linguistic domains, e.g., a) the linear order constraints model by S. Poplack; 2) non-linear constraint models by N. Chomsky, E. Woldorf; 3) Matrix Language Frame model by C. Myers-Scotton.

A. S. Poplack code-switching model deals with intra-sentential switching or using of sentences or syntagmas as their parts side-by-side while they belong to different languages thus creating "equivalence constraint" at a syntax language level while "linear 
coherence of sentence structure is ensured without omitting the duplicating lexical content" in fact, "establishing various syntactic boundaries" [20]. The main rule approves code-switching be possible under some word-order requirements for both languages. The following examples of bilingual's grammar area demonstrate the overlapping of surface syntactic structures of two languages - L1 and L2, Puerto-Rican Spanish patterns including English segments:

\section{Leo un MAGAZINE - I read a MAGAZINE.}

2. Me iban a LAY OFF - They were going to LAY me OFF'.

As is clearly seen the description of code switching is based on the monolingual approach due to the fact that bilingual syntax is view through general principles of formal grammar theories developed on the basis of monolingual studies. When the research deals with Spanish-English or English-Spanish code switching, it's more regular approach to use English as a case of monolingual grammar to analyze the pattern itself both in intrasentential and morphemic levels. Still, in the opinion of S. Poplack, there exist different patterns of adapting monolingual resources in the code-switching strategies. Further on she also remarks that code-switching differs greatly from lexical borrowings another major manifestation of language contacts (ibid).

Shortcomings of the linear order constraints model by S. Poplack might occur due to the fact that there's no attempt to explain code-switching as it proceeds from a kind of "third grammar" monolingual, by default, but although non-existent, at least, not explicit, e.g.:

(1) The students habian visto la pelicula italiana

The students had seen the Italian movie

(2) *The students had visto la pelicula italiana

The students had seen the Italian movie ${ }^{2}$.

Even more, when it comes to Free Morpheme Constraint, e.g.:

(5) *told le, le told, him deji, dije him [32: 176]

told to-him, to-him I-told, I-told him

'(I) told him'

(6) *estoy eat-iendo [5: 368]

I-am eat-ing ${ }^{3}$.

If the Poplack's model is descriptively adequate, it causes some doubts in theory especially in respect to the examples called borrowings by S. Poplack, and nonce borrowings by J. MacSwan meaning they are "borrowed items which appear for the first time" in this instances - they are not historically used in the target language, and is a borrowing indeed from the point of view of its grammatical (morphological) properties [21:57].

${ }^{1}$ We don't discuss phonological differences here. - E.K., J.M.

Citation in: MacSwan, 2000, p. 55.

3 Citation in: MacSwan, 2000, p. 56. 
B. N. Chomsky, E. Woldorf's non-linear constraint models proceeds from the core statement that code-switching mechanisms are governed by general grammatical principles which emerges from Chomsky's generative grammar and his Government and Bounding syntactic theory. The principles to govern bilingual code-switching are assumed to be all and only those governing monolingual grammar. So in this codeswitching field two models were elaborated: 1) the Government Constraint Model ([22; 23]) and 2) Functional Head Constraint Model (Belazi, Rubin, Toribio, 1994). The following the Minimalist approach seemed to sum up the models introduces stating that the only constraint in code-switching is determined by the requirements of mixed grammar [21]. In fact N. Chomsky (1991) [25] stated that parametric variations might be represented in lexicon and then be reflected in syntax: "If there were only one human language, the story would essentially end there. But we know that this is false, a rather surprising fact. The general principles of the initial state evidently allow a range of variation. Associated with many principles there are parameters with a few - perhaps just two values. Possibly, as proposed by Hagit Borer, the parameters are actually restricted to the lexicon, which would mean that the rest of the language is fixed and invariant, a far — reaching idea that has proven quite productive" [25: 23].

In Chomsky's system language grammar consists of two components: $\mathrm{C}_{\mathrm{HL}}-$ a computational system for human language, which is possibly invariant across languages, and lexicon, which is variable and in fact unique in each language. Phrase structures are derived from the lexicon in the minimalist framework and phrase trees are built derivationally by applying three operations - Select, Merge and Move. One more rule governs structure derivation: in the process of derivation, lexically encoded elements should match the course of derivation.

The leading aim of Chomsky's Minimalist Program is to eliminate all unnecessary mechanisms and apply for linguistic data minimum of theoretical assumptions which would account for code-switching, including principles and requirements of Universal Grammar. Thus it would be possible to confine code-switching to two lexicons and escape ambiguity to explain the data itself. In this case, Universal Grammar is the "Third grammar" of code-switching and only some language specific features in lexicon of particular languages may cause minor constraints to describe and classify code-switching mechanisms. The Minimalist framework helps emerge a formal theory of borrowing considering properties of a single language matter in the account of the facts of codeswitching (see: [21: 87]).

C. Matrix Language Frame model by C. Myers-Scotton. This syntactic model has got psycholinguistic theories of speech production and performance as a background. The researcher assumes that linguistic constrains of code-switching within a single sentence (or in general any intrasentential constraints) are governed by a Matrix Language Frame model, or MLF model ([26; 27]). Matrix Language (ML) dominates Embedded Language (EL) even if the elements of the Embedded Language are inserted into the morpho-syntactic Matrix Language frame.

There are few principles to make up the MLF model:

- Matrix Language used to be the first language of a speaker, so it tends to be the dominant over Embedded Language. 
- asymmetry of ML and EL projects unequal role of those languages in morphosyntactic structuring a frame of bilingual sentence: ML is more active than EL even if they work simultaneously;

- ML grammatical structure is not variable in the course of code-switching;

- Systemic morphemes emerge due to the ML function to form a bilingual utterance as a morpho-syntactic frame. Still, EL makes constraints on the ML as to different types of its morphemes - both lexical and grammatical, among those prepositions and conjunctions are more frequently used, and a few of other functional words less frequent.

Below see a few examples to illustrate code-switching ${ }^{4}$ :

\section{Hindi/English}

Life ko face kiijiye with himmat and faith in apane aap. (Code-switching)

Face life with courage and faith in self. (Translation)

\section{Swahili/English}

Hata wengine nasikia washawekwa cell. (Code-switching)

Even others I heard were put [in] cells. (Translation)

\section{Swahili/English}

*Sikuona your barau ambayo uliipoteza. (Code-switching ungrammatical)

I didn't see your letter which you lost. (Translation)

\section{Swahili/English}

*Nikamwambia anipe ruhusa niende ni-ka-check for wewe. (Code-switching, ungrammatical)

And I told him he should give me permission so that I go and check for you. (Translation)

\section{Swahili/English}

Ulikuwa ukiongea a lot of nonsense. (Code-switching)

You were talking a lot of nonsense." (Translation)

English variations show the following influence of EL:

1. Formulaic expressions and idioms (especially prepositions and other functional words: with, in, for, and; set phrases — sayings and proverbs: Face life with courage and faith in self)

2. Quantifier expressions (a lot of)

3. Non-quantifier, non-time noun phrases as verb phrase complements (a lot of nonsense check for).

The given examples demonstrate that $\mathrm{C}$. Myers-Scotton qualifies these code-switching as ungrammatical and for understanding they are accompanied with translation into English. On the one hand, it seems convenient, but it doesn't concentrate on important typological differences of languages contacting — inflexional and analytical Indo-European English and agglutinative and inflexional Bantu language Swahili. In our opinion, it'd serve better do describe even the surface morpho-syntactical structure of codeswitching between those languages. Still, due to translation, one more factor - ungram-

\footnotetext{
${ }^{4}$ Swahili-English examples are taken from: C. Myers-Scotton, 1993b.
} 
matical emerges and once again appeals to discuss the problem of code-switching and borrowings interaction. In fact, in practical grammar books and manuals Swahili-English Bantu-language structure was describe by means of the English monolingual grammar which brought a lot of misunderstanding both in teaching and learning Swahili by English-speaking communities and the same for English in Bantu-Swahili environment. Still, due to translation, one more factor - ungrammatical emerges and once again appeals to discuss the problem of code-switching and borrowings interaction.

As for C. Myer-Scotton, she views code-switching and borrowing as universally related processes because they belong to one and the same single continuum [26]. She proceeds from the idea expressed by E. Haugen [4: 373] that "borrowing always goes beyond the actual 'needs' of language" [4: 373], so any strict distinction between borrowing and code-switching is not of great demand. Studying African languages, she finally came to a conclusion about two types of borrowings - cultural and core borrowings, respectively, lexical items that are new to the recipient language culture, and those lexical items that have "viable" equivalents in the recipient language and they are actually some extra lexical means [26: 169]. The rest of the possible borrowings belong to the code-switching domain. Thus she doesn't see code-switching and borrowing as two distinct processes, nor such a distinction be crucial.

Her opponent seems to be S. Poplack who insists that code-switching differs greatly from lexical borrowing — the other major manifestation of language contacts. Her main counter-arguments concern the fact that loanwords are not involved in morphology, syntax or phonology of the lexifier language and that they are recurrent in the speech od individuals [28]. As to nonce borrowings, S. Poplack abides to understand those as neither recurrent, nor widespread, and requiring a certain bilingual competence It seems to be an arbitrary solution as to the disagreement on such topics: 1) should the distinction between code-switching and borrowing be formally recognized in the theory of codeswitching; 2) should any manifestations of language contact be unambiguously identified in bilingual discourse; and 3) what criteria could tell the difference between switching or borrowing this or that language item.

\section{QUASI-CONCLUSION: REASONS FOR CODE-SWITCHING}

If one turns to the following graph ${ }^{5}$, he might think that code-switching has nothing to do with language or linguistics proper as it presents extra-linguistic reasons to approve the notion of code-switching and discourse strategies without any discussion of structural or systemic language features, namely: mood of a speaker, show identity, some functions - referential, directive, phatic, poetic, metalinguistic; strategies - to clarify (expression, or utterance), to explain a message, quote other people, use habitual expressions.

5 The graph is borrowed from: https://yandex.ru/images/search?text=REasona $\% 20$ for $\% 20$ codeswitching $\% 20-\% 20 \mathrm{a} \% 20$ diagram\&img_url=https $\% 3 \mathrm{~A} \% 2 \mathrm{~F} \% 2 \mathrm{Fusercontent} 1$.hubstatic.com $\% 2 \mathrm{~F} 888$ 4586_f520.jpg\&pos $=0 \& \mathrm{rpt}=$ simage\&lr $=213$ (accessed: 26.03 .2018 ). 


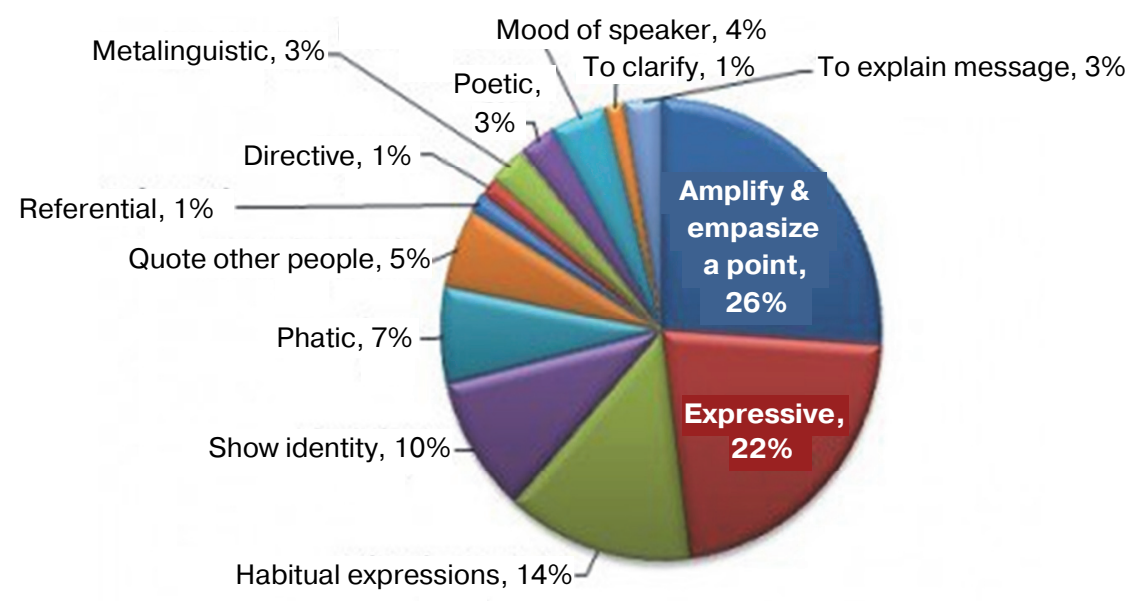

Fig. 1. Reasons for Code Switching

Certainly, the functions mentioned appeal to language but do not identify or specify its means and structures, so they are perceived as intentions in course of communication and indirectly combine extra- and intra-linguistic aspects. Still, in our opinion, the presentation helps realize the complexity of the code-switching phenomena and the necessity of its multidisciplinary studies.

Another set of reasons to develop code-switching studies could have some parallel linguistic illustrations and thus seems more linguistically proper. Still, those several reasons to switch codes mostly deal with a single conversation.

Here are important features of a successful single conversation with necessary elementary lexical and grammatical code-switching insertions ${ }^{6}$ :

- A particular topic of conversation: people generally used to switch codes during discourse about a particular topic, since it requires specific language; varieties related to a particular topic may be better able to convey or communicate issues surrounding it, e.g., people are talking about their professional task or project, so they are likely to use terms or professional lexis which seems foreign to some random listeners and may alter the sentence structure: This approach was en vogue / in vogue decades ago. Multa cum laudae is just the best evaluation // The best mark is multa cum laudae.

- Quoting someone: people have to switch codes while quoting another person or text passage, e.g., Gutta cavat lapidem non vi, sed saepe cadendo (Lat.), Your performance is great! C'est magnefique!

- Solidarity and gratitude: expressing gratitude or solidarity, people may speak in ways that express these feelings, e.g., (an Englishmen says in French) Bonne appetite! Help yourself!

- Clarification: speakers may alter their speech when listeners have trouble understanding how they communicated a thought or idea before, e.g., His novel is roman a clef // His novel is a code// a cypher.

${ }^{6}$ URL: https://yandex.ru/images/search?text=a\%20scheme\%20of\%20reasons\%20for\%20codeswitching\&stype $=$ image $\& 1 \mathrm{r}=213 \&$ source $=$ wiz $($ accessed 26.03.2018). 
- Group identity: people may alter their language to express group identification. This can happen, for example, when introducing members of a particular group to others, e.g., Mike is a computer geek//Mike is a real PC expert.

- To soften or strengthen command: while asking someone to do something, code switching works to mark emphasis or provide inspiration, e.g., My dear friend Olga, please, be on time! Mi querida Olga ...

- Lexical need: people often use some technical terms or words written in another language. In that case, if people try to translate those words, that might distort the exact meaning and value of the word or term. In this case, code switching occurs to maintain the exact meaning of the word, compare: distilled water - aqua distillata.

\section{CONCLUSION PROPER}

Studies of language contacts have a long history and actually date back to ancient times when native speakers didn't understand newcomers or foreigners they even could have called them barbarians. In modern time people used to have some problems of overcommunication never mind what language, dialect, slang or code they use. Bilingualism makes a norm in melting pots of big cities, in touristic areas all over the world, in advertising where bilingualism is to create imagery. People are not yet polyglots but tend to master mutilingualism as a lot of devices and gadgets actually provoke its appearance one of these days.

Human speech is no longer the main or even the only possible means of communication, and languages still tend to develop forming new varieties and combining linguistic items of all kinds, even phonetical resources are slightly but changing under the influence of different speech modes and patterns.

Code-switching is rather a novel field of research and in applied perspective it might help teaching and learning foreign languages and provide easier language interaction both in and out the classroom. Multilingual communication sets new ambitious goals and tasks to develop strategies of multi-disciplinary approach in mastering languages and at maximum - getting to know more about cognitive and social impact of theoretical and applied linguistic research. Because we are human, we learn lifelong, eager to get as much knowledge as possible and use it to our needs and benefits.

The three developed linguistic approaches in code-switching were reviewed in the article. All of them are combining theory and practice, they give much evidence of codeswitching between the languages of different structure and lexicon, different morphology and syntax, etc., which concerns language and language contacts from synchronic point of view. Those are: a) the linear order constraints model by S. Poplack; 2) non-linear constraint models by N. Chomsky \& E. Woldorf; 3) Matrix Language Frame model by $\mathrm{C}$. Myers-Scotton. The scholars themselves acknowledge the fact that a vast language material, unique samples of code-switching between languages of different typologies and structures stimulate the research, but it's not enough. One has to take into consideration the factors of human behavior, national cultural tradition, individual occupations and skills, many social, economic and political factors which make the study multidisciplinary.

The intralinguistic achievements in developing code-switching studies concentrate on the data accumulation: many examples are involved presenting pairs of languages 
that were and still are actively contacting due to the areal spread, tradition and history; English-Spanish in Americas, Finnish or Norwegian and English in the US territory, Bantu languages and English in Africa, Hindi-English in Asia and so on. The main method already applied is structural or more precisely, morpho-syntactical intrasentential analysis which deals with foreign insertions and is explained by means of a monolingual grammar. Three paradigms of linear, non-linear constraints and Matrix Language Frame are dealing with surface syntactic structures describing types of insertions of meaningful and functional language components in sentence structure of typologically similar or different languages. Most promising although rather complicated seems the hypothesis of MLF as it introduces the double-headed principle of interaction of Matrix language and Embedded Language

Thus the problem of monolingual or Universal grammar as a tool to measure and define code-switching effect and consequences stays in the core of methodology applied. Still, at present the result seems rather poor as the performance of analysis is limited to observation and actually 'visual' surface comparison. Besides despite the fact that languages are structurally different this fact is hardly ever taken into consideration provoking a question whether code switching could be observed between Chinese and a Bantu language?

The MLF hypothesis seems most promising but at the same time rather complicated as it introduces the double-headed principle of interaction of Matrix language and Embedded Language.

Besides grammatical and random phonological data code-switching is dealing with borrowings while not every researcher accept those for analysis because loanwords make up another research domain. Still, the so called nonce borrowings treated by E. MacSwan are far from typical loanwords and if languages "assimilate" nonce borrowings they are real code-switching phenomena.

Finally, the notion of 'code' is not a synonymic naming for language or its structure: code belongs to semiotics as it doesn't confine itself to language items despite the approved approach to understand language as a semiotic system. Although words serve to represent linguistic signs - iconic or symbolic, the intrasentensial insertions are really different from both words or morphemes, they are rather syntagmas in the classical definition of the term.

As to the terminology it also survives the state-of-the art phase as their correlation is unstable and disputable. On the one hand, just the phrase itself 'code-mixing' implies the larger spectrum of phenomena and items than 'code-switching' in comparison with code-mixing suggesting the understanding of a limited number of items and methods under review, or rather a mechanism of variations and possible change. At the same time, terms under discussion - alteration, borrowing, etc., create the impression of different phenomena - ether phonological or lexical ones.

Nevertheless, code-switching is a multidisciplinary study putting forward a linguistically rooted theory and methodology localized in bilingual and multilingual research within the language contact domain.

(C) Elena A. Krasina, Jabballa Mahmoud Mustafa X. Дата поступления: 26.10.2017

Дата приема к печати: 6.11.2017 


\section{REFRENCES}

1. Fano, R.M. (1950). The information theory point of view in speech communication. In: Journal of Acoustical Society of America, 22, 691-696.

2. Fries, W. \& Pike, K. Coexistent phonemic systems. Langusge 25: 29-50.

3. Weinreich, U. (1968). Languages in contact. The Hague: Mouton. 149 p.

4. Haugen, E. (1956). Bilingualism in the Americas: A bibliography and research guide. Alabama: University of Alabama Press: Publication of the American Dialect Society, 26. 159 p.

5. Vogt, H. (1954). Language contacts. In: Word, 10, 363-374.

6. Romaine, S. (1995). Bilingualism. Oxford: Blackwell. Xvi - 384 p.

7. Milroy, L. \& Muysken, P. (1995). Introduction. In: L. Milroy \& P. Muysken (Eds.) One speaker two languages: Cross-disciplinary perspectives on code-switching. New York: Cambridge University Press, $1-14$.

8. Lohndal, T. (2013). Generative grammar and language mixing. In: Theoretical Linguistics, 39, $215-224$.

9. Myer-Scotton, C. (1993b). Duelling languages: Grammatical structure in code-switching. Oxford: Clarendon. xiv - $263 \mathrm{p}$.

10. Gumperz, J.J. (1982-2002). Discourse strategies (Studies in Interactional Sociolinguistics, vol. 1). Cambridge: Cambridge University Press. 225 p.

11. Poplack, C. (1978). Dialect acquisition among Puerto Rican bilinguals. In: Language in Society, 7, 89-103.

12. Auer, P. (1995). The pragmatics of code-switching: a sequential approach. In: L. Milroy \& P. Muysken (Eds.) One speaker two languages: Cross-disciplinary perspectives on code-switching. New York: Cambridge University Press, 115-135.

13. Singh, R. (1985). Grammatical constraints on code-switching: Evidence from Hindi — English. In: Canadian Journal of Linguistics, 30, 33-45.

14. Shridhar, S. \& Shridhar, R. (1980). The syntax and psycholinguistics of bilingual code-mixing. In: Canadian Journal of Psychology, 34, 407-416.

15. Muysken, P. (2000). Bilingual speech: A typology of code-mixing. Cambridge: Cambridge University Press. xvi +306 p.

16. Pfaff, C. (1979). Constraints on language-mixing: Intrasentential code-switching and borrowing in Spanish/French. In: Language, 55, 291-318.

17. Poplack, C., Wheeler, S. \& Westwood, A. (1987). Distinguishing language contact phenomena: Evidence from Finnish - English bilingualism. In: P. Liliua \& M. Saari (Eds.). The Nordic languages and modern linguistics, 6. Helsinki: University of Helsinki Press. 22-56.

18. Sankoff, D. \& Poplack, C. (1981). A formal grammar for code-switching. In: Papers in Linguistics, $14,3-45$.

19. Jackobson, R. (1952). Linguistics and communication theory. In: On the structure of language and its mathematical aspects: Proceedings of the XIIth Symposium of Applied Mathematics. Providence, R.I.: Mathematical Society, 245-252.

20. Poplack, C., Meechan, M. (1995). Patterns in language mixture: Nominal structure on WolofFrench and Fongbe-French bilingual discourse. In: L. Milroy \& P. Muysken (Eds.) One speaker two languages: Cross-disciplinary perspectives on code-switching. New York: Cambridge University Press, $199-232$.

21. MacSwan, J. (2005). Précis of a Minimalist Approach to Intrasentential Code Switching. In: Italian Journal of Linguistics, 17, 55-92.

22. Wolford, E. (1983). Bilingual code-switching and syntactic theory. In: Linguistic Inquiry, 14, $520-523$.

23. Halmary, E. (1997). Government and code-switching: Explaining American Finnish. Amsterdam: J. Benjamins. 276 p.

24. Belazi, Y.M., Rubin, E.J. \& Toribio, A.J. (1994). Code-switching and X-Bar Theory: the functional head constraint. In: Linguistic Inquiry, 25, 221-237.

25. Chomsky, N. (1991). Linguistics and cognitive science: Problems and mysteries. In: Asa Kasher (ed.). The Chomskyan turn. Cambridge: Blackwell, 26-53. 
26. Myer-Scotton, C. (1993a). Social motivations for code-switching: Evidence from Africa. Oxford: Oxford University Press. xii, $177 \mathrm{p}$.

27. Myer-Scotton, C. (2002). Contact Linguistics: Bilingual encounters and grammatical outcomes. Oxford: Oxford University Press. 360 p.

28. Poplack, S., Sankoff, D. \& Miller, C. (1988). The social correlates and linguistic process of lexical borrowing and assimilation. In: Linguistics, 26 (1), 47-104.

29. Chomsky, N. (1995). The Minimalist Program. Cambridge, Mass.: MIT Press. 426 p.

30. Grinstad, M.D., Lohndal, T. \& Åfarli, T.A. Language mixing and exoskeletal theory: A case study of word-internal mixing in American Norwegian. The Arctic University of Norway. URL: http://septentrio.uit.no/index.php/nordlyd (accessed 26.03.2018).

31. MacSwan, J. (1999). Minimalist Approach to Intrasentential Code-Switching. New York: Garland Press. 305 p.

32. Poplack, C. (1980). Sometimes I'll start a sentence in English y termino en español: Towards a typology of code-switching. In: Linguistics, 18, 581-618.

33. Sankoff, D., Poplack, C. \& Vanniarajan, S. (1990). The case of the nonce loan in Tamil. In: Language variation and change, 2, 71-101.

\title{
ПЕРЕКЛЮЧЕНИЕ КОДОВ: СОВРЕМЕННОЕ СОСТОЯНИЕ
}

\section{Елена А. Красина, Жаббалла Махмуд Мустафа X.}

\author{
Российский университет дружбы народов \\ ул. Миклухо-Маклая, 6, Москва Россия, 117198
}

Переключение кодов - это один из аспектов изучения непосредственных результатов в рамках теории языковых контактов, что предполагает проведение анализа внутренней структуры предложения на уровне его морфологических и синтаксических структур с целью установления и объяснения природы языковых заимствований в синхронном плане. Одновременно переключение кодов использует и развивает психологический и социальный подходы в исследовании поведения человека, но, в первую очередь, ограничивается лингвистическим анализом. В настоящее время наиболее разработаны три ведущие лингвистические теории переключения кодов, основанные на языковых данных, а именно: линейная ограниченная словопорядковая модель S. Poplack и др.; линейная неограниченная словопорядковая модель of N. Chomsky и E. Woldorf and матричная лингвистическая фреймовая модель (Matrix Language Frame model), предложенная C. Myers-Scotton. Все три модели исходят из того, что процессом переключения кодов управляет грамматика одного из языков, участвующих в их переключении, хотя хомскианская модель заменяет такую монолигвальную грамматику на грамматику универсальную в сочетании с принципами генеративной грамматики. Модель C. Myers-Scotton оказывается наиболее сложной, поскольку она организована как двунаправленный инструмент: доминатный ML — Matrix Language не устраняет фактора языка подчиненного, или EL — Embedded Language, который в процессе их взаимодействия активен и создается впечатление своеобразного сотрудничества. Все три модели применимы в основном к описанию структуры предложения, и таким образом формируется исследование его внутренней структуры, хотя также делаются выводы и относительно морфологических и даже фонологических аспектов высказывания-предложения. Лексикон контактирующих языков практически исключается из анализа, но N. Chomsky, J. MacSwan и C. Myers-Scotton обращают внимание на лексические заимствования; они доказывают важность их учета, вводя понятие окказионализма, или nonce borrowing для особого представления в языке культуры и традиций. В действительности современное положение дел в исследовательской сфере переключения кодов базируется исключительно на наблюдении и накоплении языковых фактов и материалов в целях дальнейшего структурного анализа контактирующих языков. Недостатки такого подхода могут объясняться тем, что в процедуре анализа не используются типологические языковые характеристики, поэтому собственно анализ не опира- 
ется на твердую основу, а использует случайные данные, не приводящие к какой-либо возможной их классификации. Поэтому возможно предположить, что к настоящему моменту основные результаты исследования переключения кодов стоит искать в области методологии и методов. Терминологии в области переключения кодов находится в стадии становления: даже исходный термин «код», по нашему мнению, требует более однозначного определения, поскольку исходно он не характеризует язык как таковой, а относится к семиотическим системам различной природы и устройства.

Направления дальнейших исследований не ограничиваются исключительно билингвальными или мультилингвальными данными, но требуют углубленного междисциплинарного — мультидисциплинарного изучения языковых контактов и верификации причин переключения кодов с использованием комплекса ресурсов гуманитарного и естественно-научного знания применительно к лингвистическим единицам и кодам.

Ключевые слова: языковые контакты, переключение кодов, смешение кодов, заимствование, линейная ограниченная словопорядковая модель/линейная неограниченная словопорядковая модель, матричная лингвистическая фреймовая модель, внутренняя структура предложения, вкрапление

\section{Для цитирования:}

Красина Е.А., Жаббалла Махмуд Мустафа Х. Переключение кодов: современное состояние // Вестник Российского университета дружбы народов. Серия: Теория языка. Семиотика. Семантика, 2018. Т. 9. № 2. С. 403-415. doi: 10.22363/2313-2299-2018-9-2-403-415.

\section{For citation:}

Krasina E.A., Jabballa Mahmoud Mustafa X. (2018). Code-Switching: State-of-the Art. RUDN Journal of Language Studies, Semiotics and Semantics, 9 (2), 403-415. doi: 10.22363/2313-2299-20189-2-403-415.

Elena A. Krasina, Jabballa Mahmoud Mustafa X., 2018. RUDN Journal of Language Studies, Semiotics and Semantics, 9 (2), 403-415. doi: 10.22363/2313-2299-2018-9-2-403-415.

\section{Сведения об авторе:}

Красина Елена Александровна, доктор филологических наук, профессор, профессор кафедры общего и русского языкознания филологического факультета Российского университета дружбы народов, работает на кафедре с 1980 года. Она ведет теоретические курсы и на русском, и на английском языках: Теория и история языкознания, Общее языкознание, Филология в системе гуманитарного знания, прикладной курс Методы лингвистического анализа. Сфера научных интересов: теоретическое и прикладное языкознание, анализ текста и дискурса, теоретический синтаксис, лингвистическая семиотика, семантика и прагматика. Опубликовала более 100 работ: это научные статьи, учебники и учебные пособия, две монографии; e-mail: elena_krassina@mail.ru

Жаббалла Махмуд Мустафа Х (Ливия), аспирант третьего года обучения на кафедре общего и русского языкознания филологического факультета Российского университета дружбы народов, пишет диссертацию в рамках контрастивного и типологического анализа структурно различных языков - английского и арабского.

\section{Bio Note:}

Krasina Elena Aleksandrovna. Dr. habilis, Professor of the General and Russian Linguistic Department, Philological Faculty, the RUDN University, is working in the department from 1980. She's teaching theoretical linguistic courses both in Russian and English: Theory and History of Linguistics, General Linguistics, Philology in the System of Humanities, including the applied course of Methods of Linguistic Analysis. Sphere of scientific research: theoretical and applied linguistics, text and discourse studies, text analysis, theoretical syntax, linguistic semiotics, semantics and pragmatics. She's got over 100 publications — articles, manuals, monographs; e-mail: elena_krassina@mail.ru

Jabballa Mahmoud Mustafa X. (Libya). A third year PhD student of the General and Russian Linguistic Department, Philological Faculty, the RUDN University, the making research in the field of contrastive and typological studies of structurally different language — English and Arabic. 